\title{
PERAN TEKNOLOGI INFORMASI DAN KOMUNIKASI UNTUK MENINGKATKAN KUALITAS PEMBELAJARAN DALAM PERSPEKTIF KURIKULUM 2013
}

\author{
Marzoan \\ STKIP Hamzar Lombok Utara \\ Lokok Aur Desa Karang Bajo Kec. Bayan Kab. Lombok Utara 83354 \\ Email : marzoanswandy@gmail.com
}

\begin{abstract}
ABSTRAK
Tulisan ini bertujuan untuk mengkaji peran Teknologi Informasi dan Komunikasi dalam meningkatkan kualitas pembelajaran dalam sudut pandang Kurikulum 2013 sebagai kurikulum baru pengganti kurikulum 2006 (KTSP). Kajian dalam tulisan ini menggunakan metode kajian pustaka dari sumber-sumber primer. Sumber data berupa dokumen. Analisis difokuskan pada upaya menemukan, mengidentifikasi, dan menganalisis secara kritis unsurunsur penting dalam dokumen kurikulum 2013 yang dikaitkan dengan kajian dari beberapa litaratur yang relevan. Dari berbagai dokumen yang dianalisis dapat disimpulkan bahwa dalam Kurikulum 2013 terdapat beberapa perubahan, salah satu yang terkait dengan peran Teknologi Informasi dan Komunikasi adalah dihapusnya mata pelajaran TIK dan sebagai penggantinya TIK menjadi alat bantu guru dalam proses pembelajaran pada semua mata pelajaran. Hal ini berimplikasi pada pentingnya penguasaan TIK oleh guru. Bila proses pembelajaran dilakukan berbantukan TIK, maka diyakini akan meningkatkan kualitas pembelajaran.
\end{abstract}

Kata Kunci : TIK, pembelajaran, kurikulum

\section{ROLE OF INFORMATION AND COMMUNICATION TECHNOLOGY TO IMPROVE THE QUALITY OF LEARNING IN PERSPECTIVE CURRICULUM 2013}

\begin{abstract}
This paper aims to examine the role of ICT in improving the quality of learning in the light of the new curriculum. Curriculum 2013 as the replacement for the curriculum in 2006 (KTSP). Study in this paper using a literature review of primary sources. Source of data in the form of documents. The analysis focused on finding, identifying, and analyzing critically important elements in the curriculum document 2013 that is associated with the study of some relevant litaratur. Of the various documents that were analyzed can be concluded that in 2013 there were some changes in curriculum, one of which related to the role of Information and Communication Technology is the removal of subjects ICT and ICT as a tool replacement teacher in the learning process in all subjects. This has implications for the importance of mastery of ICT by teachers. When the learning process is done ICT, it is believed to improve the quality of learning.
\end{abstract}

Keywords: ICT, learning, curriculum 


\section{PENDAHULUAN}

Peran teknologi informasi dan komunikasi dewasa ini sudah tidak diragukan lagi karena sudah teraktualisasi dalam hampir setiap lini kehidupan dan tidak dapat dilepaskan dari kebutuhan umat manusia, pun demikian pada institusi pendidikan. Sebagai hasil rekayasa pengetahuan, teknologi umumnya dipahami sebagai sebuah transformasi ilmu pengetahuan ke dalam produk, proses, jasa dan struktur organisasi sehingga menghasilkan sesuatu yang konkrit dan siap pakai. Atas dasar itu, banyak orang lalu beranggapan bahwa teknologi dapat memecahkan segala masalah, termasuk masalahmasalah yang berkaitan dengan bidang pendidikan. Pandangan demikian tentu tidak sepenuhnya benar, karena masalah pendidikan adalah masalah yang kompleks. Namun demikian, hampir semua meyakini bahwa pemanfaatan teknologi informasi dan komunikasi dapat berkontribusi positif terhadap peningkatan kualitas mutu pendidikan.

Pemanfaatan TIK dalam proses pembelajaran seperti sudah tidak dapat dipisahkan dari dunia pendidikan. Seperti diketahui, bahwa dalam struktur Kurikulum 2013, teknologi informasi dan komunikasi tidak lagi sebagai mata pelajaran yang diajarkan, akan tetapi teknologi informasi dan komunikasi akan menjadi sarana pembelajaran pada semua mata pelajaran. Artinya, meskipun tidak dicantumkan sebagai mata pelajaran, namun keterampilan menggunakan peralatan teknologi informasi dan komunikasi mutlak digunakan untuk kelancaran proses pembelajaran. Konsekuensi logis dari hal ini adalah, lembaga pendidikan/sekolah harus memiliki infrastruktur memadai yang mendukung pembelajaran berbasis TIK dan guru dituntut untuk mampu merancang dan menghasilkan media pembelajaran yang berbasiskan TIK seperti merancang media pembelajaran berbasis komputer, mendesain strategi pembelajaran berbasis web, mengelola pembelajaran dengan blanded learning dan lainlain.

Menurut Simanjuntak (2013), melaksanakan tututan kurikulum seperti disebutkan di atas, bukanlah hal yang mudah, sebab berhubungan dengan bagaimana merubah mindset para guru dari sebelumnya sebagai satusatunya sumber belajar menjadi fasilitator dalam proses pembelajaran, sehingga diperlukan kebijakan yang mendukung guru untuk terus menerus belajar dan melatih dirinya dengan pengetahuan dan keterampilan menggunakan TIK. Permasalahan yang muncul kemudian adalah, media dan peralatan TIK mana yang digunakan oleh guru dalam proses pembelajaran? Apakah media dan peralatan TIK tersebut dapat memenuhi karakteristik peserta didik yang berbeda? Dan bagaimana dengan kemampuan awal peserta didik terhadap media dan peralatan TIK tersebut?.

Berbagai permasalahan tersebut di atas, dialami oleh sebagian besar guru dan perlu segera dicarikan alternatif solusinya. Tulisan ini diikhtiarkan untuk mengkaji bagaimana meningkatkan kualitas pembelajaran dengan pemanfaatan Teknologi Informasi dan Komunikasi dalam sudut pandang kurikulum baru (Kurikulum 2013) sebagai pedoman penyelenggaraan pembelajaran yang sudah 
disahkan/ditetapkan oleh pemerintah bebebrapa waktu lalu. Tulisan ini merupakan hasil studi yang dilakukan melalui kajian pustaka (literature review) dari dokumen-dokumen yang berkaitan dengan kurikulum 2013.

\section{PEMBAHASAN}

\section{Karakteristik Kurikulum 2013}

Secara konseptual kurikulum diartikan sebagai seperangkat rencana dan pengaturan mengenai tujuan, isi, dan bahan pelajaran serta cara yang digunakan sebagai pedoman penyelenggaraan kegiatan pembelajaran untuk mencapai tujuan pendidikan tertentu (UU nomor 20 tahun 2003; PP nomor 19 tahun 2005). Dalam praktiknya, kurikulum digunakan untuk mempersiapkan peserta didik dalam menghadapi tantangan-tantangan di masa depan melalui pengetahuan, keterampilan, sikap dan keahlian untuk beradaptasi serta bisa bertahan hidup dalam lingkungan yang senantiasa berubah. Dalam rangka beradaptasi dengan berbagai tuntutan kehidupan itulah kemudian perubahan kurikulum menjadi sebuah keniscayaan.

Perubahan kurikulum dari KTSP (Kurikulum 2006) menjadi Kurikulum 2013 juga kurang lebih dalam semangat yang sama, yaitu dalam rangka menyesuaikan diri dengan perkembangan mutakhir dalam menghadapi berbagai tantangan kehidupan baik yang bersifat internal maupun eksternal, di masa kini dan masa yang akan datang. Bila mencermati Dokumen Uji Publik K-13, nampak bahwa perubahan itu diperlukan karena dilatarbelakangi oleh masih terdapat beberapa permasalahan pada Kurikulum 2006 (KTSP) antara lain ; (1) Konten kurikulum masih terlalu padat yang ditunjukkan dengan banyaknya mata pelajaran dan banyak materi yang keluasan dan kesukarannya melampaui tingkat perkembangan usia anak; (2) Kurikulum belum sepenuhnya berbasis kompetensi sesuai dengan tuntutan fungsi dan tujuan pendidikan nasional; (3) Kompetensi belum menggambarkan secara holistik domain sikap, keterampilan, dan pengetahuan; (4) Beberapa kompetensi yang dibutuhkan sesuai dengan perkembangan kebutuhan (misalnya pendidikan karakter, metodologi pembelajaran aktif, keseimbangan soft skills dan hard skills, kewirausahaan) belum terakomodasi di dalam kurikulum; (5) Kurikulum belum peka dan tanggap terhadap perubahan sosial yang terjadi pada tingkat lokal, nasional, maupun global; (6) Standar proses pembelajaran belum menggambarkan urutan pembelajaran yang rinci sehingga membuka peluang penafsiran yang beraneka ragam dan berujung pada pembelajaran yang berpusat pada guru; (7) Standar penilaian belum mengarahkan pada penilaian berbasis kompetensi (sikap, keterampilan, dan pengetahuan) dan belum tegas menuntut adanya remediasi secara berkala; (8) Dengan KTSP memerlukan dokumen kurikulum yang lebih rinci agar tidak menimbulkan multi tafsir. Bila demikian kenyataannya, maka pengembangan kurikulum menjadi sebuah kebutuhan, terlepas dari berbagai persoalan dalam proses implementasinya.

Kurikulum 2013 diperlukan untuk menjawab kebutuhan kompetensi generasi emas Indonesia pada tahun 2045 atau 100 tahun sejak Indonesia merdeka (Nuh, 2013). Hal ini relevan dengan satu prinsip pengembangan kurikulum, yaitu kurikulum harus tanggap terhadap 
perkembangan ilmu pengetahuan, budaya, teknologi, dan seni. Kurikulum dikembangkan atas dasar kesadaran bahwa ilmu pengetahuan, budaya, teknologi, dan seni berkembang secara dinamis. Oleh karena itu konten kurikulum harus selalu mengikuti perkembangan ilmu pengetahuan, budaya, teknologi, dan seni; membangun rasa ingin tahu dan kemampuan bagi peserta didik untuk mengikuti dan memanfaatkan secara tepat hasil-hasil ilmu pengetahuan, teknologi, dan seni (Dokumen K13).

Ada beberapa hal pokok yang mengalami penyempurnaan dalam kurikulum 2013, diiantaranya adalah isi kurikulum dan mata pelajaran. Dua komponen tersebut diuraikan secara ringkas untuk memberikan gambaran mengenai perubahan karakteristik Kurikulum 2013 bila dibandingkan dengan kurikulum sebelumnya. Pertama, Isi Kurikulum. Dalam dokumen Kurikulum 2013 isi kurikulum dikembangkan dalam bentuk Kompetensi Inti (KI) dan Kompetensi Dasar (KD). Kompetensi Inti dikembangkan dari Standar Kompetensi Lulusan (SKL) dan merupakan kualitas minimal yang harus dikuasai peserta didik di kelas untuk setiap mata pelajaran. Kompetensi Inti terdiri atas jenjang kompetensi minimal yang harus dikuasai peserta didik di kelas tertentu, isi umum materi pembelajaran, dan ruang lingkup penerapan kompetensi yang dipelajari. Jenjang kompetensi dalam KI meningkat untuk kelaskelas berikutnya, KI tidak memuat konten khusus mata pelajaran tetapi konten umum, yaitu fakta, konsep, prosedur, metakognitif dan kemampuan menerapkan pengetahuan yang terkandung dalam setiap mata pelajaran.
Perluasan penerapan kompetensi yang dipelajari dinyatakan dalam KI, dimulai dari lingkungan terdekat sampai ke lingkungan global. Dalam design Kurikulum 2013, KI berfungsi sebagai pengikat bagi KD. Dalam fungsi sebagai pengikat, setiap KD yang dikembangkan untuk setiap mata pelajaran di setiap kelas harus mengacu kepada KI.

Kompetensi Inti terdiri atas empat dimensi yang satu sama lain saling terkait, yaitu sikap spiritual (KI 1), sikap sosial (KI 2), pengetahuan (KI 3), dan keterampilan (KI 4). Keempat dimensi tersebut tercantum dalam pengembangan KD, silabus, dan RPP. Dalam proses pembelajaran, KI 1 dan $\mathrm{KI} \quad 2$ dikembangkan dalam proses pendidikan di setiap kegiatan di sekolah (kelas dan luar sekolah) dengan pendekatan pembelajaran tidak langsung. KI 3 dan KI 4 dikembangkan oleh setiap mata pelajaran dalam pendekatan pembelajaran langsung. Kompetensi Inti (KI 3) menitikberatkan pada pengembangan pengetahuan (faktual, konseptual, prosedural, dan metakognitif) dalam jenjang kemampuan kognitif dari mengingat sampai mencipta. KI 4 merupakan perencanaan kegiatan belajar untuk menerapkan apa yang dipelajari di KI 3 dalam suatu proses pembelajaran yang terintegrasi ataupun terpisah. Terintegrasi mengandung arti bahwa proses pembelajaran KI 3 dan KI 4 dilakukan pada waktu bersamaan baik di kelas, laboratorium maupun di luar sekolah. Terpisah mengandung makna bahwa pembelajaran mengenai KI 3 terpisah dalam waktu dan/atau tempat dengan KI 4. Keputusan mengenai pembelajaran terintegrasi atau terpisah ditentukan sepenuhnya dalam silabus dan RPP, 
berdasarkan pertimbangan mengenai konten KD untuk KI 3 dan KD untuk KI 4 (Buku Guru PAI Kemendikbud, 2014:3)

Kedua, mata pelajaran. Salah satu ciri kurikulum 2013 yaitu adanya penambahan jam pelajaran. Penambahan jam pelajaran sebagai konsekuensi dari adanya perubahan proses pembelajaran yang semula dari siswa diberi tahu menjadi siswa mencari tahu. Selain itu, akan merubah pula proses penilaian yang semula dari berbasis output menjadi berbasis proses dan output. Setiap mata pelajaran dalam Kurikulum 2013 memuat konten spesifik (pengetahuan), dan konten berbagi (sikap dan keterampilan yang berasal dari mata pelajaran lain). Dengan konsepsi ini, mata pelajaran secara langsung menjadi sumber bahan ajar yang spesifik dan berbagi untuk dikembangkan dalam dimensi proses suatu kurikulum. Mata pelajaran pada setiap jenjang diorganisasi menjadi dua kelompok. Untuk pendidikan dasar (SD/MI \& SMP/MTs), terdiri dari Kelompok A, yaitu kelompok mata pelajaran yang memberikan orientasi kompetensi lebih kepada aspek intelektual dan afektif; dan Kelompok B, yaitu kelompok mata pelajaran yang lebih menekankan pada aspek afektif dan psikomotor. Adapun untuk SMA/MA/SMK terdiri dari mata pelajaran wajib yang diikuti oleh seluruh peserta didik, dan mata pelajaran peminatan (pilihan) yang diikuti oleh peserta didik sesuai dengan bakat, minat, dan kemampuannya (Kemendikbud, 2012).

Dalam kaitannya dengan TIK, dalam struktur Kurikulum 2013, mata pelajaran TIK sudah ditiadakan dengan pertimbangan bahwa TIK akan menjadi sarana pembelajaran pada semua mata pelajaran, artinya mata pelajaran TIK tidak akan diajarkan lagi di sekolah dasar dan menengah, akan tetapi TIK menjadi alat bantu guru dalam proses pembelajaran pada semua mata pelajaran. Hal ini berarti bahwa semua komponen pendidikan yang ada dituntut untuk bersinergi dengan TIK, kondisi ini sekaligus menegaskan bahwa peran TIK dalam Kurikulum 2013 menjadi sangat penting dan menentukan untuk memajukan mutu pendidikan.

\section{Peran TIK dalam Meningkatkan Kualitas Pembelajaran}

Simajuntak (2013) mengelompok-kan pemanfaatan TIK dalam pendidikan menjadi 4 (empat) kelompok manfaat, yaitu: TIK sebagai gudang ilmu pengetahuan, sebagai alat bantu pembelajaran, sebagai fasilitas pembelajaran, dan sebagai infrastruktur pembelajaran.

1) Sebagai gudang ilmu pengetahuan, TIK dimanfaatkan sebagai referensi ilmu pengetahuan terkini, manajemen pengetahuan, jaringan pakar beragam bidang ilmu, jaringan antar institusi pendidikan, pusat pengembangan materi ajar, wahana pengembangan kurikulum, dan komunitas perbandingan standar kompetensi.

2) Sebagai alat bantu pembelajaran, TIK dapat dimanfaatkan dalam proses pembelajaran, misalnya sebagai alat bantu guru dan peserta didik dalam menggunakan metode atau sumber belajar, sebagai alat bantu interaksi guru-peserta didik.

3) Sebagai fasilitas pembelajaran, TIK dapat dimanfaatkan sebagai: perpustakaan elektronik, kelas virtual, aplikasi 
multimedia, kelas teater multimedia, kelas jarak jauh, papan elektronik sekolah, alat ajar multiintelejensia, pojok internet, dan komunikasi kolaborasi kooperasi (intranet sekolah)

4) Sebagai infrastruktur pembelajaran, TIK memberikan dukungan teknis dan aplikatif untuk pembelajaran, baik dalam skala menengah maupun luas, yang meliputi: ragam teknologi kanal distribusi, ragam aplikasi dan perangkat lunak, bahasa pemprograman, sistem basis data, komputer personal, alat-alat digital, sistem operasi, sistem jaringan dan komunikasi data, dan infrastruktur teknologi informasi (media transmisi).

Resnick (2002) menyebutkan bahwa untuk modernisasi pendidikan paling tidak ada tiga hal penting yang harus dipikirkan kembali, yaitu : How people learn (bagaimana kita belajar); what people learn (apa yang kita pelajari); dan where and when people learn (kapan dan di mana kita belajar).

Sehubungan dengan ini Wahid (2005) menyatakan bahwa How people learn berkaitan dengan metode atau model pembelajaran yang digunakan oleh guru dalam proses pembelajaran. Hal ini relevan dengan Kurikulum 2013 yang menekankan pendekatan pembelajaran yang berpusat pada siswa (student-centered learning) bahwa proses pembelajaran sudah tidak sepenuhnya bergantung kepada guru (instructor dependent), guru bukan lagi sebagai satu-satunya sumber belajar tetapi lebih sebagai fasilitator atau konsultan.

Bentuk peran TIK dalam hal ini misalnya melalui sistem pembelajaran berbasis web yang populer dengan sebutan electronic learning (e-learning), web-based training (WBT) atau kadang disebut web-based education (WBE), m-learning (mobile learning), dan lain-lain. Keunggulan belajar jarak jauh yang ditawarkan oleh teknologi ini adalah akses ke sumber belajar semakin terbuka dan luas, cepat dan tidak terbatas pada ruang dan waktu. Kegiatan pembelajaran dapat dengan mudah dilakukan oleh guru dan siswa, kapan saja dan di mana saja dengan rasa nyaman dan menyenangkan. Batasan ruang, waktu dan jarak tidak lagi menjadi masalah rumit untuk dipecahkan. Melalui teknologi e-learning guru dan siswa bisa melakukan konferensi, diskusi, konsultasi secara elektronik (electronic conference) tanpa harus bertemu disuatu tempat (Rusman, 2009).

Secara umum, intervensi e-learning dalam proses pembelajaran dapat dikelompokkan menjadi tiga fungsi, yaitu: (1) sebagai tambahan (suplemen) yang sifatnya pilihan (opsional); tidak ada kewajiban bagi peserta didik untuk mengakses materi $e$ learning. Sekalipun sifatnya opsional, peserta didik yang memanfaatkannya tentu akan memiliki tambahan pengetahuan atau wawasan. (2) sebagai pelengkap (complement); materi $e$ learning diprogramkan untuk menjadi materi reinforcement (pengayaan) atau remedial bagi peserta didik di dalam mengikuti kegiatan pembelajaran konvensional. (3) pengganti (substitusi); e-learning sebagai alternatif model pembelajaran.

Adapun untuk pertanyaan what people learn? Menurut Wahid (2005) berkaitan dengan kurikulum, apakah kurikulum telah sesuai 
dengan kebutuhan siswa dan apakah kurikulum telah dirancang untuk menyiapkan siswa untuk hidup dan bekerja pada masa yang akan datang. Bila melihat pertimbangan yang digunakan pemerintah dalam melakukan perubahan kurikulum, maka dalam konteks ini menjadi sangat relevan. Tidak dapat dipungkiri bahwa TIK begitu mewarnai dunia pendidikan saat ini dan TIK juga mengubah tidak hanya terhadap apa yang seharusnya dipelajari oleh siswa, tetapi juga apa yang dapat dipelajari. Sangat mungkin banyak hal yang seharusnya atau dapat dipelajari siswa tetapi tidak bisa dimasukkan ke dalam kurikulum karena "ruang" yang terbatas atau kompleksitas yang tinggi dalam mengajarkannya. Terkait dengan ini, paradigma pembelajaran yang sebelumnya mengandalkan bahwa sumberdaya pembelajaran hanya terbatas pada materi di kelas dan buku harus diubah.

Pertanyaan where and when people learn? mengarah pada apakah proses pembelajaran harus di ruangan kelas dalam waktu tertentu atau tidak terbatas ruang dan waktu? Dalam hal ini e-learning sekali lagi hadir untuk memberikan kebebasan kepada siswa dalam memilih tempat, waktu, dan ritme belejar. Interaksi yang difasilitasi oleh TIK ini dapat terjadi secara sinkron (pada waktu yang sama) maupun asinkron (dalam waktu yang berbeda). Dengan e-learning, siswa dapat belajar di mana saja dan kapan saja tanpa hadirnya guru di dekat mereka. Misalnya e-learning menggunakan CDROM (multimedia), siswa dapat membuka pelajaran tersebut kembali di rumah dan dapat belajar sendiri.

Memaksimalkan peran TIK dalam meningkatkan kualitas pembelajaran harus diawali dengan perubahan paradigma. Dalam pandangan Wahid (2005) penggunaan TIK tidak sama dengan otomatisasi. TIK tidak hanya memecahkan masalah dengan menggantikan pekerjaan yang selama ini dilakukan dengan manual menjadi berbantuan teknologi. Jika paradigma berpikir itu yang digunakan, maka pemanfaatan TIK tidak akan membawa perubahan radikal. Cara berpikir deduktif (deductive thinking) seperti ini tidak banyak memunculkan perubahan yang radikal terkait dengan pemanfaatan TIK dibandingkan jika berpikir secara induktif (inductive thinking). Pemahaman terhadap potensi yang ditawarkan oleh TIK adalah cara berpikir induktif. Jika TIK ingin dioptimalkan pemanfaatannya dalam pembelajaran, maka harus diawali dengan berpikir induktif. Potensi TIK harus dikenali dengan baik terlebih dahulu, kemudian mencari masalah yang mungkin dipecahkan. Pertanyaan yang harus dimunculkan adalah bagaimana menggunakan TIK untuk mengerjakan apa yang belum dikerjakan serta bagaimana mengoptimalkan potensi TIK untuk meningkatkan apa yang telah dikerjakan. Dengan demikian, akhirnya, TIK dapat diekspoitasi untuk mendapatkan manfaat yang maksimal.

\section{Peran Guru dalam Pembelajaran Berbasis TIK}

Perubahan kurikulum sudah dapat dipastikan akan berimplikasi bagi guru, karena guru merupakan ujung tombak penerapan kurikulum. Seperti diketahui, bahwa kurikulum memiliki dua sisi yang sama pentingnya yakni kurikulum sebagai dokumen dan kurikulum 
sebagai implementasinya. Sebagai sebuah dokumen kurikulum berfungsi sebagai pedoman bagi guru dan kurikulum sebagai implementasi adalah realisasi dari pedoman tersebut dalam kegiatan pembelajaran. Guru merupakan salah satu faktor penting dalam implementasi kurikulum. Bagaimanapun idealnya suatu kurikulum tanpa ditunjang oleh kemampuan guru untuk mengim-plementasikannya, maka kurikulum itu tidak akan bermakna. Oleh karena itu, kesiapan guru dalam mengim-plementasikan kurikulum harus mendapat perhatian, baik menyangkut kompetensi, komitmen dan tanggung jawabnya serta kesejahteraannya. Kompetensi guru bukan saja menguasai apa yang harus dibelajarkan (content) tapi bagaimana membelajarkan siswa yang menantang, menyenangkan, memotivasi, menginspirasi dan lain-lain. Dalam konteks inilah guru dituntut untuk dapat memanfaatkan TIK dalam proses pembelajaran.

Seperti disebutkan sebelumnya, bahwa dalam struktur kurikulum 2013 TIK menjadi alat bantu (tools) bagi guru dalam melaksanakan proses pembelajaran pada semua mata pelajaran. Kondisi ini menuntut kesiapan guru untuk dapat merancang dan menghasilkan media maupun sumber belajar yang berbasiskan TIK. Pesatnya perkembangan TIK berdampak pada pergeseran peran guru dalam pembelajaran, yaitu : (1) peran guru yang pada awalnya hanya sebagai sumber utama informasi dan sumber jawaban, menjadi fasilitator pembelajaran, pelatih, kolaborator, navigator pengetahuan, dan mitra belajar; (2) peranan guru dalam mengendalikan semua aspek pembelajaran sudah tidak berlaku lagi, tetapi lebih banyak memberikan alternatif dan tanggung jawab kepada peserta didik dalam proses pembelajaran.

Salah satu kemudahan dalam kurikulum 2013, guru tidak lagi disibukkan memikirkan silabus, sehingga guru akan leluasa mengembangkan kreativitas dalam mengajar. Guru lebih dapat menfokuskan diri dalam mengembangkan pendekatan pembelajaran saintific (rekomendasi pendekatan pembelajaran dalam Kurikulum 2013) dengan mengarahkan anak didik untuk melakukan pengamatan (observing), menanya (questioning), menalar (assosiating), mencoba (experimenting) dan membentuk jejaring (networking). Namun demikian, untuk dapat mengembangkan kreativitas dan menerapkan pendekatan pembelajaran tersebut harus dibarengi dengan kemampuan teknis guru dalam menggunakan perangkat media pembelajaran berbasis TIK.

Agar guru dapat mengim-plementasikan kurikulum 2013 di sekolah dengan baik, Farisi (2013) menyarankan kepada guru untuk melakukan rekonstruksi peran-peran pedagogisnya yang dicirikan oleh kemampuan pedagogis sebagai: (1) pengambil keputusan (decision maker), guru mampu menstimulasi siswa untuk berpikir, bersikap, dan bertindak aktif dan reflektif dalam belajar; mendorong terjadinya dialog; dan melakukan evaluasi-diri terhadap gagasan, nilai, sikap, dan tindakan yang diambil; (2) reformer yang reflektif (reflective reformer), guru bersikap terbuka untuk mengeksplorasi gagasan dirinya; mampu berpikir kritis-reflektif daripada berpikir secara kategorikal; mampu mentoleransi terjadinya konflik gagasan dan cita-cita antara dirinya dengan siswa; mampu mengenali nilai-nilai yang 
bersifat kontroversial; memiliki kesadaran bahwa pengetahuan bersifat relatif dan probabilistik terhadap konteks; (3) partisipan kooperatif (cooperative participant), guru selalu terbuka untuk bekerjasama dengan siswa di dalam berbagai aktivitas belajar yang dilakukan, mendorong para siswa untuk menggunakan caracara berpikir alamiah dan intuitifnya; (4) agen katalisator (catalytic agent) bagi hasil-hasil penemuan siswanya; (5) peran didaktik (didactic roles), guru berperan reflektif dan afektif, yakni pengembang konsep siswa, dan pengembang keterampilan siswa dalam mengambil keputusan-keputusan yang tepat dalam berbagai isu, nilai, kepercayaan yang seringkali bersifat kontroversial.

\section{KESIMPULAN}

Dari berbagai dokumen yang dianalisis dapat disimpulkan bahwa dalam Kurikulum 2013 terdapat beberapa perubahan, salah satu yang terkait dengan peran Teknologi Informasi dan Komunikasi adalah dihapusnya mata pelajaran TIK dan sebagai penggantinya TIK menjadi alat bantu guru dalam proses pembelajaran pada semua mata pelajaran.

Tidak dapat dipungkiri bahwa tuntutan kurikulum yang menekankan penggunaan perangkat TIK dalam pembelajaran akan mengalami banyak kendala terutama di sekolahsekolah pedalaman, karena hal tersebut berkaitan dengan kesiapan guru dan ketersediaan sarana prasarana penunjang pembelajaran seperti jumlah komputer, jaringan internet, listrik dan lain-lain.

Di atas itu semua, guru merupakan ujung tombak penerapan kurikulum dan kunci sukses implementasi kurikulum 2013, oleh karena itu guru harus mendapat perhatian pemerintah menyangkut kompetensinya dalam penguasaan TIK, pada saat yang sama guru juga dituntut memiliki kesadaran untuk menyiapkan dan mengembangkan diri dalam menguasai teknik pembelajaran berbasis Teknologi Informasi dan Komunikasi. Kemampuan ini bukanlah pilihan, tapi merupakan kebutuhan sesuai dengan tuntutan kurikulum 2013.

\section{DAFTAR PUSTAKA}

Farisi, M.I., 2013. Kurikulum Rekonstruksionis dan Implikasinya terhadap Ilmu Pengetahuan Sosial: Analisis Dokumen Kurikulum 2013. Pedagogia : Jurnal Penelitian Pendidikan ISSN 1026 4109. Jilid 16 Nomor 2 Agustus 2013.

Kemendikbud. 2012. Dokumen Kurikulum 2013. Jakarta

Kemendikbud. 2012. Dokumen Uji Publik Kurikulum 2013. Jakarta

Kemendikbud. 2014. Buku Guru Pendidikan Agama Islam dan Budi Pekerti untuk SMA/MA/MAK. Jakarta.

Kemendikbud. 2003. Undang-Undang Republik Indonesia Nomor 20 Tahun 2003 Tendang Sistem Pendidikan Nasional. Jakarta.

Kemendikbud. 2014. Peraturan Menteri Pendidikan dan Kebudayaan Republik Indonesia Nomor 70 Tahun 2013 tentang Kerangka Dasar dan Struktur Kurikulum Sekola Menengah Kejuruan/Madrasah Aliyah Kejuruan. Jakarta.

Nuh, M. 2013. Kurikulum 2013. Harian Kompas. (Jumat, 8 Maret 2013)

Resnick, M. 2002. Rethinking Learning in the Digital Age. Dalam Porter, M. E., Sachs, J. D., dan McArthur, J. W. The Global Information Technology Report 20012002: Readiness for the Networked World.

Rusman. 2009. Manajemen Kurikulum. Jakarta : PT. RajaGrafindo Persada. 
Simanjuntak, D. 2013. Peranan Teknologi Informasi dan Komunikasi dalam Kurikulum 2013. Jurnal Pendidikan Penabur - No.21/Tahun ke-12/Desember 2013.
Wahid, F. 2005. Peran Teknologi Informasi dalam Modernisasi Pendidikan Bangsa. Disampaikan dalam Simposium Nasional Peduli Pendidikan. Fakultas Teknologi Industri, Universitas Islam Indonesia, Yogyakarta, pada 9 Juli 2005. 